The University of San Francisco

USF Scholarship: a digital repository @ Gleeson Library |

Geschke Center

Economics, Law, and International Business

School of Management

1998

\title{
Continuing Duty to Warn: Public Policy and Managerial Views
}

Karl Boedecker

University of San Francisco, boedecker@usfca.edu

Fred W. Morgan

Allen Saviers

Follow this and additional works at: http://repository.usfca.edu/elib

Part of the Business Law, Public Responsibility, and Ethics Commons

\section{Recommended Citation}

Karl Boedecker, Fred Morgan and Allen Saviers, “Continuing Duty to Warn: Public Policy and Managerial Views," Journal of Public Policy \& Marketing, 17 (Spring), 127-131. 1998

This Article is brought to you for free and open access by the School of Management at USF Scholarship: a digital repository @ Gleeson Library | Geschke Center. It has been accepted for inclusion in Economics, Law, and International Business by an authorized administrator of USF Scholarship: a digital repository@Gleeson Library| Geschke Center. For more information, please contact repository@usfca.edu. 


\title{
Continuing Duty to Warn: Public Policy and Managerial Views
}

\author{
Karl A. Boedecker, Fred W. Morgan, \\ and Allen B. Saviers
}

The authors explicitly consider the public policy issues related to the question of post-sale warnings and offer suggestions on how marketers should handle these issues.

$\mathbf{T}$ The topic of post-sale warnings is fraught with uncertainty and trade-offs. Commentators note that companies encounter several difficulties meeting their postsale warning responsibilities (Jacobs 1992; Schwartz 1983; Van Kirk 1989) and that it might be easier to fulfill time-ofsale warning obligations (Matula 1996). In his article in this issue of the Journal of Public Policy \& Marketing, Schwartz (1998) addresses three important topics with regard to postsale warnings: (1) whether marketers should have a postsale duty to warn; (2) given that the draft version of the Restatement of the Law of Torts: Products Liability (1997) includes a post-sale duty to warn, what is the appropriate nature and scope of such duty; and (3) under what circumstances should a marketer have to undertake a product recall?

He considers these issues in the context of both the Model Uniform Product Liability Act (1979) and the American Law Institute's Restatement of the Law of Torts: Products Liability (1997) project. I Schwartz states that marketers should have a post-sale duty to warn, albeit a limited one. The nature of this duty should be fault based and grounded in traditional negligence concepts rather than strict liability. He describes approvingly its narrowly drawn scope in the draft Restatement and advises that a company should have a "company-wide protocol," a contingency plan for assessing the need for post-sale warnings. He concludes that when marketers undertake voluntary product recalls, they should be shielded from liability, unless they act recklessly in doing so. Throughout his article, Schwartz maintains a managerial perspective by focusing on the implications of these policy issues for managers. He does, however, raise a public policy concern when he questions the fairness of what he labels "hindsight jurisprudence," that is, holding a company

ISchwartz drafted the Model Uniform Product Liability Act and played a major role in shaping the Restatement of the Law of Torts: Products Liability (1997).

Karl A. Boedecker is Professor of Law, University of San Francisco. Fred W. MORGAN is Professor of Marketing, University of Kentucky. Allen B. SAviers is Senior Contract Administrator, WorldCom Network Services. responsible for product dangers, unrecognized before the product launch, that come to light afterwards.

Our objectives in this comment are to (1) consider explicitly the important public policy issues related to the question of post-sale warnings and (2) offer some additional suggestions about how marketing managers should handle postsale warnings and recalls.

\section{Public Policy Issues Inherent in the Question of Post-Sale Warnings}

In a society that enjoys a highly developed economy with many technologically complex products, a certain number of product-related injuries are inevitable. Consumers have become accustomed to a continuing cycle of new products, and companies compete with one another to be the first to provide these new offerings. This interaction raises two key public policy issues:

1. Allocating the risks of product-related injuries. Who should bear those risks and in what proportions?

2. Apportioning the losses from product-related injuries. At one extreme, marketers would bear these losses in the form of absolute tort liability, that is, having to pay the total cost of any such injuries, regardless of fault or product defect. At the other extreme, consumers themselves would absorb these losses without any legal recourse against marketers. (Insurance has a key role here, but on whom should premium costs fall-marketers or consumers? Placing those insurance costs on marketers might cause them to raise prices accordingly, thereby effectively shifting that burden onto product purchasers. This is now a widespread practice.)

Moreover, we live in a society with a sophisticated marketing and distribution system, in which many businesses, often far removed from and beyond the awareness of consumers, perform various marketing functions as part of the distribution channel. Under these circumstances, what policies will provide maximum incentives for marketers to take active roles in maintaining product safety throughout the stream of commerce?

\section{Public Policy Issues with Regard to Warnings}

The public policy underlying current law requires that products sold to consumers must be safe in terms of design, manufacture, and warnings, with warnings acting as a compensatory factor for products that cannot be designed to be com- 
pletely safe. ${ }^{2}$ Warnings must be given to consumers when the product is dangerous in a manner that is not readily determinable by examining it or by using it in a foreseeable manner, even one unintended by the marketer. These principles lead to three important considerations. How hidden, or latent, is the danger? How severe is the danger? What product uses or misuses are foreseeable?

Each of these questions involves a judgment about the behavior of persons coming in contact with the product. The less obvious or more severe the danger, the greater the duty to warn. To the extent that a product use is foreseeable, regardless of whether it is intended by the seller, a warning must accompany the product. Because of the difficulty in identifying the "bright line" that separates situations that require warnings from those that do not, companies tend to err on the side of caution, and warnings proliferate (Fuller 1997; Rechtschaffen 1996; Tyson 1987), which leads to information overload (Weissman 1996; Zeckhauser and Viscusi 1990).

Before products reach the marketplace, companies are in a position to anticipate unusual uses through product testing, test marketing, focus groups, and brainstorming sessions. If a firm should thereby discover uses that expose consumers to an unreasonable risk of harm, warnings can be appended to products to notify consumers not to engage in these dangerous practices. Or, more fundamentally, products can be redesigned with, for example, warning sounds, deadman switches, restricted motions, or protective devices, so as to reduce the chances that consumers will use products incorrectly.

When the firm learns of a product's dangerous propensities after its introduction, the options available to the firm are limited and differ in scope and effectiveness: do nothing, warn current and future customers, or recall the product. Rare is the situation in which a company would take no action to respond to recently discovered product shortcomings. Even if the problem creates minor risks to consumers, a series of incidents could lower consumers' perceptions of the product and thereby reduce future sales.

In determining whether to issue a post-sale warning, a firm is influenced by the laws and judicial decisions in the jurisdictions in which it operates, as well as by the recently issued Restatement of the Law of Torts: Products Liability (1997). The Restatement (1997, \$10) provides four guidelines for evaluating the continuing duty to warn (see also

${ }^{2}$ A critical public policy question not fully discussed in this analysis is the relationship between design and warnings. The core questions is: To what extent should legally adequate warnings be allowed to offset unsafe product designs? For many products, the dangers cannot be "designed away." For example, many pharmaceutical products are safe if the prescribed dosages are ingested. The only way to prevent overdosing is to sell single doses; however, this would be inconvenient and expensive. So drug products are marketed with warnings regarding proper dosages. The design versus warning trade-off actually involves a third factor: cost of an absolutely safe design-if such a design exists.

The same issues arise in the batting helmet example raised by Schwartz. Children seem to be willing to do almost anything. A prudent manufacturer might attempt to issue warnings that address any and all unintended uses, that is, anything not related to the act of batting in the context of playing or practicing baseball. A question that is more perplexing as a public policy matter is whether such a manufacturer should be relieved of liability because its attorneys drafted a thorough warning that the children either cannot or do not read and retain.
Lazarus et al. 1997; Wittner 1997): (1) the seller knows or reasonably should know that the product poses a substantial risk of harm to persons or property, (2) those to whom a warning might be provided can be identified and reasonably assumed to be unaware of the risk of harm, (3) a warning can be effectively communicated to and acted on by those to whom a warning might be provided, and (4) the risk of harm is sufficiently great to justify the burden of providing a warning.

Each of these guidelines is explicated in the context of a reasonable person in the seller's position. But because the company is trying not only to "do the right thing," but also to avoid subsequent liability, the company must anticipate what a trier of fact (jury or judge) eventually might believe a reasonable person should do under the circumstances.

The extent to which the marketer reasonably can be expected to learn about product-related problems is the critical determination regarding the necessity for a post-sale warning. When regarded collectively as a distribution channel, marketers are in a better position than consumers to know about and deal with product-related dangers. Many of these dangers are not tangible to consumers-they take the form of colorless, odorless, invisible substances. Or, they exist as apparently harmless everyday objects that can have carcinogenic effects over time, such as asbestos fibers, toxic emissions, or radiation. The company is better equipped than consumers, either at the time of sale or post-sale, to learn about a product's dangerous properties through testing.

The only caveat regarding relative knowledge might be in situations that involve corporate consumers, for example, a company that purchases industrial equipment for use in making the products it sells. But here the user's knowledge might be, at best, equivalent to that of the salespeople and designers of the equipment. It is difficult to imagine a situation in which product users are clearly more informed about product-related dangers than product marketers.

If the seller claims not to have known about dangerous product features, the issue becomes one of constructive knowledge (i.e., did the seller have reason to know). A marketing organization with standard research and testing facilities will have a difficult time convincing a trier of fact that it was unaware of product-related dangers.

The issue of seller knowledge involves the notion of hindsight jurisprudence that Schwartz raises. The cornerstone tort principle of foreseeability, often assessed according to what a reasonable marketer "knew or should have known" at the time of product sale, invokes the notion of hindsight because this determination occurs after a claim has been made. Thus, such judgments inevitably entail hindsight. Allocating responsibility by applying a standard that assesses whether a party possessed appropriate knowledge seems both fair and desirable. A trier of fact should be allowed to determine whether the marketer's actions were reasonable in light of what it knew or should have known before placing the product into the stream of commerce.

The absence of a hindsight knowledge standard could lead to situations in which defendants are exonerated because they were unaware of product-related dangers due to inadequate product testing. Sound public policy involves providing incentives (penalties) for companies to know whether their products are safe before offering them for sale. 
The following hypothetical example illustrates several of these post-sale warnings and repair issues.

\section{A Hypothetical Case Example}

Soda Bottling Company (Soda) bottles and distributes several brands of soft drinks. Soda has purchased and used several different models of vending machines, including those manufactured by the Vend-O Company. In September 1997, Soda receives a letter from Vend-O regarding safety problems with some of Vend-O's machines. Vend-O's letter states that (1) at least some of its machines have a tendency to dispense a can of cola when tilted or rocked and (2) several accidents have occurred when its machines have been tipped over on to people, resulting in serious injuries and deaths. Enclosed with the letter is a sample warning label decal, along with an offer to send Soda as many warning decals as it needs. Vend-O further offers to sell (at cost) safety kits to all its customers to secure the machines to walls or floors, thereby eliminating the risk of tip-over. Soda decides not to use any of Vend-O's warning decals and also declines to order any safety kits.

In November 1997, a 17-year-old high school student rocks one of Soda's vending machines, which tips over and crushes him. The machine was manufactured by Quickserve, but it uses the same generic mechanical design as the model made by Vend-O and about which Vend-O wrote the warning letter. The machine improperly allows a drink to be dispensed when the machine is tilted.

The deceased teenager's estate sues both Soda and Quickserve under several product liability claims. During the trial, evidence is presented by other students that it was wellknown at the school that this particular machine would (1) often dispense a free drink when the machine was rocked or tilted and (2) sometimes fail to dispense a drink when the full purchase price was properly deposited. However, it is unclear from the students' testimony whether the decedent had deposited money into the machine.

The plaintiff's mechanical engineering expert testifies that the vending machine model in question looks stable to the average layman but is in fact highly unstable because of a "top-heavy" design that allows it to be pushed over surprisingly easily. In addition, the expert states that when the machine is tilted and dispenses a free drink, the next paying customer buys an empty space and receives no product. The same expert opines that the machine's combination of tendencies has the effect of entrapping both paying and nonpaying customers into rocking the unstable machine.

Another important witness is Soda's technician, who services the machines at the high school. The technician testifies that he has received several complaints from school officials regarding the machine's propensity to take money without dispensing the paid-for drink. According to his testimony, the technician explained to school officials that the machine was not broken and that the problem was with people tilting the machine to get free drinks. The solution, he told the school, was to either bolt the machine down or attach warning stickers to it. However, the technician made no effort to do either.

Analysis of Soda's liability appears to fit well in the postsale duty to warn as set forth in the new Restatement (1997). Several factors indicate that Soda knew of a foreseeable risk of harm to its customers, yet failed to take measures to prevent it. On receiving the letter from Vend-O, Soda had actual knowledge of a dangerous condition associated with the purchase of its product from machines that it owned. The customers at risk included a target market comprised of minors on their high school premises, a group notoriously insensitive to risks associated with what they perceive as "routine highjinks." Furthermore, a Soda employee had acknowledged to school officials both the propensity of its machines to take money without dispensing a drink and that people could obtain free drinks by tilting the machines. The technician apparently made no effort to see that school officials took any subsequent action. Soda would be liable.

Quickserve's liability is less certain under the new Restatement standard. Quickserve's actual knowledge of the risks posed by its vending machines is unclear under these facts. Suppose that it did not know of either its machines' instability or their tendency to dispense cans when rocked or tilted. Should it have known of these defects before offering them for sale to bottlers such as Soda? If not, should it have become aware of them after having sold them but before the claim occurred? The new Restatement would impose a postsale duty to warn on Quickserve if the company knew or should have known after the time of sale or distribution that the product posed a substantial risk of harm to persons or property. That question can be answered only after a claim is made, that is, in hindsight.

In any event, another manufacturer that used the same design has discovered the dangerous condition and warned Soda. If Vend-O could discover this, why couldn't Quickserve? Furthermore, Vend-O's offers of warning labels and a safety kit to Soda make it likely that the vending machine instability problem had become known to the industry. Certainly Quickserve should have been aware of it by then.

In a case similar to this hypothetical case, the defendants, the bottler and vending machine manufacturer, were granted summary judgment by a North Carolina trial court (Morgan v. Cavalier Acquisition Corporation 1993). However, a state appellate court reversed this decision, stating that, among other issues, there were genuine questions regarding whether the defendants should have warned about the vending machine's instability. ${ }^{3}$

The outcome hinges on whether it is believed that Soda should be held accountable for knowing about a misuse of its product and not issuing post-sale warnings or installing safety devices to try to forestall the misuse. If Soda is allowed to invoke the "no hindsight" defense, then Soda is exculpated.

\section{How Marketing Managers Should Handle Post-Sale Warnings and Recalls}

When a marketing manager first learns about a productrelated risk of harm after the launch, his or her initial step

\footnotetext{
${ }^{3}$ In another similar case, the defendants were granted summary judgment because they could show that the plaintiff was trying to steal a soft drink from the vending machine (Oden v. Pepsi Cola Bottling Company of Decatur Inc. 1993). In Alabama, as in many states, someone cannot bring a cause of action based all or in part on an illegal act. The dissenting opinion in Oden, more than twice the length of the majority opinion, would have allowed a jury to determine if Pepsi should have provided warnings on its vending machines.
} 
should be to assess the potential dangers. This involves immediate contact with distributors, retailers, and consumers to learn about the number and frequency of incidents, the severity of harm (both actual and potential), the surrounding circumstances, and any unanticipated product uses. The results may indicate a need for additional product testing, beyond what the firm did prior to the introduction, that takes into account newly discovered conditions and uses. If the firm subsequently determines a need for product redesign or reformulation or a change in manufacturing processes, it should consider undertaking a product recall. In situations in which both the risk of injury and severity of harm are low, a post-sale warning might suffice.

These alternatives are not mutually exclusive. A proactive firm can choose to issue immediate warnings while it organizes and implements a recall campaign.

The firm must decide whether it has a duty to warn or recall. This requires weighing the gravity and scope (number of persons and value of property affected) of the risk, the timing and substance of the firm's knowledge, the extent to which the firm has asserted actual or constructive control over the product, and the ability of the firm to remedy the defect.

A proactive response by Soda, upon learning of Vend-O's warning and safety kit offer, would have been to accept Vend-O's offer of warning labels and have its own personnel attach them to their vending machines as soon as possible. In addition, Soda should have worked with high school officials to provide additional warnings to students through announcements, bulletin board notices, the student newspaper, and any other available means of communications. 4 Soda also should have undertaken an immediate inspection of all its vending machines to determine the necessity and feasibility of attaching them to walls or floors or otherwise securing them.

A proactive response by Quickserve would have been to devise and dispense warnings immediately to its machine purchasers, both past and current. It needed to spread the word about this potential misuse of its product as quickly as possible throughout the industry. The company also should have offered information and assistance to its customers regarding the advisability and means of stabilizing its machines. If retrofitting was not possible, Quickserve should have considered a product recall. Over the long term, product redesign appears inevitable.

\section{Protocols for Product Recalls}

The scope and difficulty of a product recall campaign depend on the nature of the market and the distribution channel that leads to it. At one extreme, in which the firm deals with a small number of readily identifiable customers (e.g., the Space Shuttle or jumbo jet aircraft, such as DC-10s), notification is straightforward. For motor vehicles, a mandatory, government-maintained registration system enables marketers to reach virtually $100 \%$ of product owners.

\footnotetext{
${ }^{4}$ Although it does not fall within the post-sale duty to warn or recall issues, the high school would have liability for the claim because it was on notice of an unreasonably dangerous condition on its premises, yet failed to
} act.
Other products pose greater challenges. Although marketers of such items as home appliances, consumer electronics, and power tools often encourage purchasers to register the items, not all consumers do so. Whenever possible, marketers should maintain customer databases that include model and serial numbers, addresses, and dates of purchase. Likewise, marketers should maintain such records for their distribution channels. Modern information technology makes the development and maintenance of such management information systems both technically possible and economically feasible.

When such information systems are not feasible, as is the case for many convenience goods, such as household cleaning products, over-the-counter pharmaceuticals, and packaged foods, marketers should track achieved distribution by geographic area and retail outlets. Again, the technology exists to do this with universal product codes and widespread checkout scanning of retail transactions. This captures the necessary data at the point of sale and allows ready access to it. Not long ago, the best that marketers could do in this regard were store audits and consumer surveys-difficult, time-consuming, and of questionable accuracy.

\section{Development and Dissemination of Post-Sale Warnings}

When marketers discover an unanticipated product hazard after the product's introduction, time is likely to be of the essence in communicating a warning to users. Such pressure might preclude the sort of warning tests that prudent marketers otherwise should conduct as a standard part of the product development process, much as they test advertising messages and alternative media delivery plans.

At the very least, however, marketers should consider not only message content and how the target audience will perceive it, but also the likelihood that the warning will reach the users. For consumer products, this raises questions of how strongly to word the message, whether to provide it in languages other than English (or use symbols), what communication media to use, how much to budget for advertising and other communication efforts, and how long the warning campaign should run. Although specific decisions will depend on the particular facts and circumstances involved, the marketer's original promotional expenditures and the length of the campaign preceding discovery of the defect are bound to weigh heavily in determining what constitutes a reasonable post-sale warning effort.

Determining the appropriate target audience for a postsale warning involves particularly significant, and difficult, problems. For many consumer products, the purchaser is not necessarily the sole user. Many household members other than the registered owner of a motor vehicle also might use it. Neighbors commonly borrow tools. Professional housecleaners use products purchased by their clients. Thus, a warning addressed to the purchaser may not reach the user, especially if the warning appears on the package or in the instructions that the buyer discards before the user sees it.

Similar problems arise with industrial products. Schwartz states that notifying employers about hazards associated with tools and machinery used in manufacturing should suffice to absolve industrial goods marketers from responsibility for product-related defects that cause injury to users. 
This assumes that employers will pass along warnings to their employees effectively. For a variety of reasons, ranging from simple oversight to a belief that such warnings would inhibit or impede worker productivity, employers might fail to do so. Indeed, any employer that does not act reasonably to convey such warnings to its employees nonetheless has the protection of the workers' compensation system, which severely restricts the employer's obligation to make the injured worker whole. In instances in which effectively conveying the warning to workers would lead to changes in workplace practices that affect productivity adversely, employers would have an economic incentive to dilute the warning or not communicate it at all.

\section{Conclusion}

If marketers are not held accountable for communicating safety-related information learned after their products are marketed and sold, consumers continually will be subject to dangers about which they could have been warned. The product marketer is usually in the best position in the distribution channel to learn about post-sale problems with a product through communications with resellers and consumers. The marketer then can determine how best to pass this safety-related information on to current and prospective product users.

\section{References}

Fuller, Peter (1997), “Warning: Don't Eat This Column," The Indianapolis Star, (March 12), A10.

Jacobs, Michael S. (1992), "Toward a Process-Based Approach to Failure-to-Warn Law," North Carolina Law Review, 71 (November), 121-99.

Lazarus, Alan J., Diane P. Duvall, W. Kennedy Simpson, Carol Dan Browning, Marjorie A. Farris, Philip E. Mischke, Pamela Y. McFarland, and Sheila Doyle Kelley (1997), "Recent Developments in Products, General Liability, and Consumer Law," Tort \& Insurance Law Journal, 32 (Winter), 499-515.
Matula, Michael L. (1996), "Manufacturers' Post-Sale Duties in the 1990s," Tort \& Insurance Law Journal, 32 (Fall), 87-112.

Model Uniform Product Liability Act (1979), 44 Federal Register $\S 212, \$ 62,714$ (October 31).

Morgan v. Cavalier Acquisition Corporation (1993), 111 N.C.App. 520, 432 S.E.2d 915; cert. denied, 335 N.C. 238,439 S.E.2d 149.

Oden v. Pepsi Cola Bottling Company of Decatur Inc. (1993), 621 So. 2d 953 (Ala.).

Rechtschaffen, Clifford (1996), "The Warning Game: Evaluating Warnings Under California's Proposition 65," Ecology Law Quarterly, 23, 303-68.

Restatement of the Law of Torts: Products Liability (1997), American Law Institute, (Proposed Final Draft-preliminary version, October 18, 1996; approved by the American Law Institute, May 20, 1997).

Schwartz, Victor E. (1983), "The Post-Sale-Duty to Warn: Two Unfortunate Forks in the Road to a Reasonable Doctrine," New York University Law Review, 58 (October), 892-904.

$\rightarrow-$ (1998), "Continuing Duty to Warn: An Opportunity for Liability Prevention or Exposure," Journal of Public Policy \& Marketing, 17 (1), 124-26.

Tyson, Patrick R. (1987), "The Preemptive Effect of the OSHA: Hazard Communication Standard on State and Community Right to Know Laws," University of Notre Dame Law Review, 62 (1987), 1010-23.

Van Kirk, Robert A. (1989), "The Evolution of Useful Life Statutes in the Products Liability Reform Effort," Duke Law Journal, 1989 (December), 1689-751.

Weissman, Kenneth Ian (1996), “A 'Comment J' Parry to Howard Latin's 'Good' Warnings, Bad Products, and Cognitive Limitations," St. John's Law Review, 70 (Fall), 629-91.

Wittner, Nicholas J. (1997), “A User's Guide: Navigating the New Restatement," Product Liability Law and Strategy, 16 (August), 4-6.

Zeckhauser, Richard J. and W. Kip Viscusi (1990), "Risk Within Reason," Science, 248 (May 4), 559-72. 